\title{
Perbandingan Penggunaan Heated Humidified High Flow Oxygen Therapy dan Low Flow Oxygen Therapy pada Pasien dengan Hipoksemia: Tinjauan Kasus Berbasis Bukti
}

\author{
Yosilia Nursakina, Yogi Prawira \\ Departemen Ilmu Kesehatan Anak Fakultas Kedokteran Universitas Indonesia/RS. Dr. Cipto Mangunkusumo, Jakarta
}

\begin{abstract}
Latar belakang. Selama ini, penggunaan low flow oxygen therapy sebagai terapi pada pasien dengan hipoksemia memiliki angka kegagalan terapi yang tinggi dan toleransi pasien yang rendah. Literatur menunjukkan bahwa heated humidified high flow oxygen therapy dapat memperbaiki oksigenasi, angka keberhasilan terapi, dan kenyamanan pasien.

Tujuan. Membandingkan efek penggunaan heated humidified high flow oxygen therapy dengan low flow oxygen therapy.

Metode. Penelusuran literatur secara terstruktur dilakukan melalui Pubmed ${ }^{\oplus}$, ScienceDirect ${ }^{\oplus}$, Proquest ${ }^{\oplus}$, dan EBSCO ${ }^{\circledR}$.

Hasil. Didapatkan dua studi acak terkontrol dan satu studi pendahuluan yang relevan. Ketiga studi menunjukkan bahwa heated humidified high flow oxygen therapy memiliki angka keberhasilan terapi yang lebih tinggi daripada low flow oxygen therapy dengan nilai NNT berturut-turut 5,55, 5,00, dan 9,09. Tidak ada perbedaan durasi rawat inap, kecepatan pernapasan, dan saturasi oksigen yang signifikan pada ketiga studi tersebut.

Kesimpulan. Penggunaan heated humidified high flow oxygen therapy terbukti aman dan meningkatkan angka keberhasilan terapi pada pasien dengan hipoksemia. Sari Pediatri 2019;21(3):195-201
\end{abstract}

Kata kunci: heated humidified high flow oxygen therapy, low flow oxygen therapy, hipoksemia

\section{Heated Humidified High Flow Oxygen Therapy versus Low Flow Oxygen Therapy in Hypoxemic Patients: Evidence Based Case Report}

Yosilia Nursakina, Yogi Prawira

Background. The use of low flow oxygen therapy in hypoxemic patients has high incidence of treatment failure and low compliance of the patients. Hence, heated humidified high flow oxygen therapy has higher success rate and better compliance.

Objective. To compare the effects of heated humidified high flow oxygen therapy and low flow oxygen therapy in hypoxemic patients Methods. Systematic literature searching was done using Pubmed ${ }^{\oplus}$, ScienceDirect ${ }^{\oplus}$, Proquest ${ }^{\oplus}$, and EBSCO ${ }^{\oplus}$.

Result. Two relevant RCTs and one pilot study were found. These studies shown that heated humidified high flow oxygen therapy has a higher success rate than low flow oxygen therapy with NNT 5,55, 5,00, and 9,09, respectively. There were no significant difference between length of stay, respiratory rate, and oxygen saturation.

Conclusion. The use of heated humidified high flow oxygen therapy is safe and has high success rate in hypoxemic patients.

Sari Pediatri 2019;21(3):195-201

Keywords: heated humidified high flow oxygen therapy, low flow oxygen therapy, hypoxemia

Alamat korespondensi: Yogi Prawira. Departemen Ilmu Kesehatan Anak Fakultas Kedokteran Universitas Indonesia/RS. Dr. Cipto Mangunkusumo, Jakarta. Email: yogi.picu@gmail.com 
$\mathrm{P}$ ada pasien dengan hipoksemia diperlukan tata laksana berupa terapi oksigen, yaitu pemberian oksigen dengan konsentrasi lebih besar dari konsentrasi oksigen di udara $(20,9 \%)$. Selain mengatasi hipoksemia, terapi oksigen juga dapat menurunkan usaha napas dan mengurangi kerja miokardium yang sebelumnya mengalami peningkatan sebagai kompensasi terhadap keadaan hipoksemia. ${ }^{1}$ Pemantauan terapi oksigen dapat dilakukan melalui pemeriksaan tingkat kesadaran, frekuensi jantung, frekuensi napas, tekanan darah, sirkulasi perifer, dan ada atau tidaknya sianosis. Bila memungkinkan, dilakukan pula pemantauan variabel fisiologis melalui pulse oxymeter (non invasif) atau analisis gas darah (invasif). ${ }^{2}$

Sistem pemberian oksigen dibagi menjadi dua, yakni sistem aliran rendah (low flow) dan sistem aliran tinggi (high flow). Pada low flow oxygen therapy, $\mathrm{FiO}_{2}$ yang diberikan umumnya tidak akurat karena sangat tergantung pada aliran inspirasi pasien. Selain itu, pada pasien anak juga sering terjadi kebocoran sistem, kanula nasal yang tidak terpasang dengan benar, dan keterbatasan kalibrasi flow meter. Hal ini berbeda dengan sistem aliran tinggi yang memberikan oksigen dengan $\mathrm{FiO}_{2}$ yang tetap dan tidak tergantung inspirasi pasien. ${ }^{3}$ Sistem aliran rendah juga memiliki toleransi yang buruk dan dan kelembaban yang suboptimal. ${ }^{4}$ Walaupun demikian, low flow oxygen therapy lebih ekonomis dan nyaman. Contoh dari sistem ini ialah kanula nasal, sungkup muka sederhana, serta sungkup dengan reservoir (sungkup muka nonrebreather, sungkup muka partial rebreather). ${ }^{2}$

Pada pasien dengan gagal napas hipoksemik, kebutuhan aliran inspirasi udara pasien umumnya tinggi dan melebihi aliran oksigen yang dihantarkan melalui alat terapi oksigen sederhana. Alat yang dapat memenuhi kebutuhan ini disebut heated humidified high flow nasal cannula (HHHFNC) yang merupakan alternatif dari terapi oksigen konvensional. Sistem ini umumnya berupa alat ventura yang bekerja berdasarkan prinsip Bernoulli, yaitu tekanan gas mengalir paling rendah pada kecepatan aliran yang paling tinggi hingga $60 \mathrm{l} /$ menit. dengan konsentrasi oksigen yang konsisten antara $21-100 \%$. Aliran gas yang dipanaskan dan dilembabkan $\left(37^{\circ} \mathrm{C}\right.$ dengan kelembaban $44 \mathrm{mg}$ $\mathrm{H}_{2} \mathrm{O} / \mathrm{L}$ ) menjaga mukosa hidung, memperbaiki fungsi mukosilier, serta membuat pasien lebih nyaman. Sistem ini juga dapat menginduksi pengurangan efek $\mathrm{CO}_{2}$ pada faring sehingga meminimalisir penghirupan ulang $\mathrm{CO}_{2}$, mengurangi ruang rugi, dan meningkatkan ventilasi alveolar. ${ }^{4}$ Kecepatan aliran yang tinggi juga dapat menurunkan resistensi nasofaringeal, usaha napas yang restriktif, serta meningkatkan tekanan saluran nasofaringeal yang puncaknya terdapat pada akhir ekspirasi ("PEEP" effect). ${ }^{5}$ Sejumlah studi menunjukkan bahwa penggunaan sistem ini tidak hanya meningkatkan saturasi oksigen, tetapi juga tekanan parsial oksigen arterial, mencegah hiperkarbia, menurunkan frekuensi napas pada IGD, menangani gagal napas akut, mencegah atelektasis pascaoperatif, serta mengurangi dispnea pada gagal jantung akut. ${ }^{6-8}$

\section{Kasus}

Anak perempuan usia 2 tahun 1 bulan pascaoperasi living donor liver transplantation (LDLT) akibat sirosis hati et causa kista duktus koledokus. Pasien memiliki riwayat pneumonia terkait rumah sakit, diare akut, hipertensi derajat 1 , serta riwayat perdarahan saluran cerna. Pasien juga mengalami gizi buruk dengan berat badan $8 \mathrm{~kg}$ dan panjang badan $72 \mathrm{~cm}$. Pada hari perawatan ke-14 pasca operasi, pasien mengalami gangguan pernapasan dengan peningkatan usaha napas, retraksi dada, dan napas cuping hidung. Hasil analisis gas darah dengan low flow oxygen therapy menunjukkan asidosis metabolik dengan hipoksemia $\left(\mathrm{pH} 7,413 ; \mathrm{PCO}_{2} 23,1 ; \mathrm{pO}_{2} 79,8 ; \mathrm{HCO}_{3} 15 ; \mathrm{BE}\right.$ $-7,3$; dan $\mathrm{SpO}_{2}$ 96,2). Hasil foto toraks menunjukkan adanya infiltrasi pada lobus superior dextra. Pasien kemudian diberikan terapi HHHFNC 12 1/menit

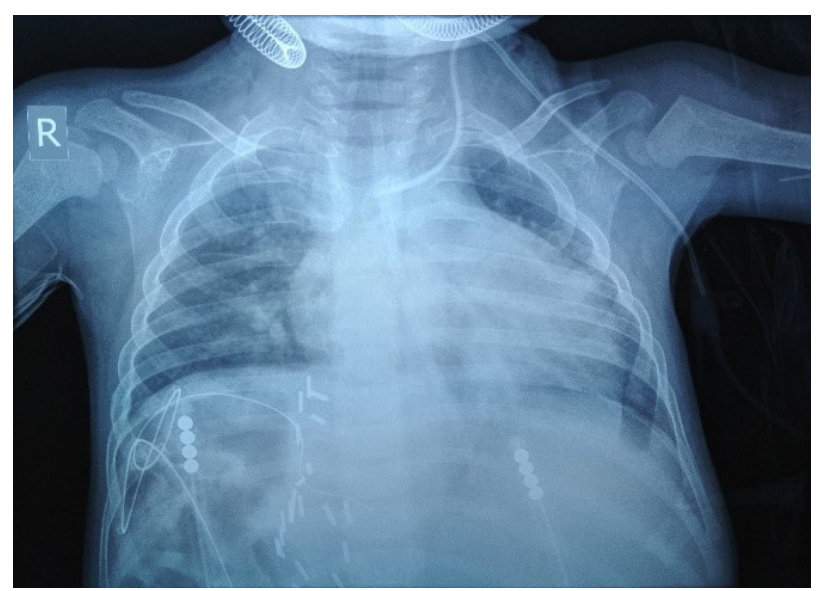

Gambar 1. Gambaran foto toraks pasien. Sumber : Rekam Medis RSCM 
dengan $\mathrm{FiO}_{2}$ 30\%. Keesokan harinya, usaha napas membaik dengan perbaikan tanda vital. Hasil analisis gas darah pasien pascaterapi HHHFNC menunjukkan $\mathrm{pH} 7,361 ; \mathrm{pCO}_{2} 38,4 ; \mathrm{pO}_{2} 138,4 ; \mathrm{HCO}_{3} 21,9 ; \mathrm{BE}$ -2,5; dan $\mathrm{SpO}_{2}$ 98,6\%.

\section{Metode penelusuran}

Pelusuran artikel dilakukan pada tanggal 24 April 2018 menggunakan empat database besar, yakni Pubmed $^{\circ}$, ScienceDirect ${ }^{\circ}$, Proquest ${ }^{\circ}$, dan EBSCO ${ }^{\circ}$. Kata kunci yang digunakan ialah "hypoxemia", "pediatric", "child", "infant", "heated humidified high flow nasal cannula", "high flow oxygen therapy", "low flow nasal cannula", "conventional oxygen therapy", dan "standard nasal cannula". Seluruh kata kunci dikombinasikan dengan Boolean operators. Literatur yang muncul pada saat penelusuran kemudian disesuaikan dengan kriteria inklusi yang meliputi: 1) berbahasa Inggris; 2) berupa studi terapeutik dan studi klinis; 3) relevan dengan pertanyaan klinis; 4) dipublikasi dalam 5 tahun terakhir; dan 5) dilakukan pada pasien anak-anak.

Berdasarkan penelusuran melalui Pubmed ${ }^{\circledR}$, terdapat 1 artikel yang sesuai kriteria dari total 6 artikel yang ditemukan. Pada penelusuran melalui ScienceDirect ${ }^{\circ}$, ditemukan 0 artikel yang sesuai dari total sebanyak 53 artikel. Sementara itu, berdasarkan penelusuran melalui Proquest ${ }^{\circledR}$ terdapat 2 artikel yang sesuai dari 43 artikel yang ditemukan. Selain itu, dari EBSCO juga didapatkan 1 artikel dari total 7 artikel yang ditemukan. Hand searching juga dilakukan dengan mencari jurnal secara manual dan ditemukan 3 artikel yang sesuai dengan kriteria inklusi dan eksklusi. Tujuh artikel tersebut kemudian dilakukan filtering double, skrining abstrak, dan pencarian full text, sehingga diketahui bahwa terdapat 3 artikel yang dapat digunakan dalam tinjauan kasus berbasis bukti dengan topik ini.

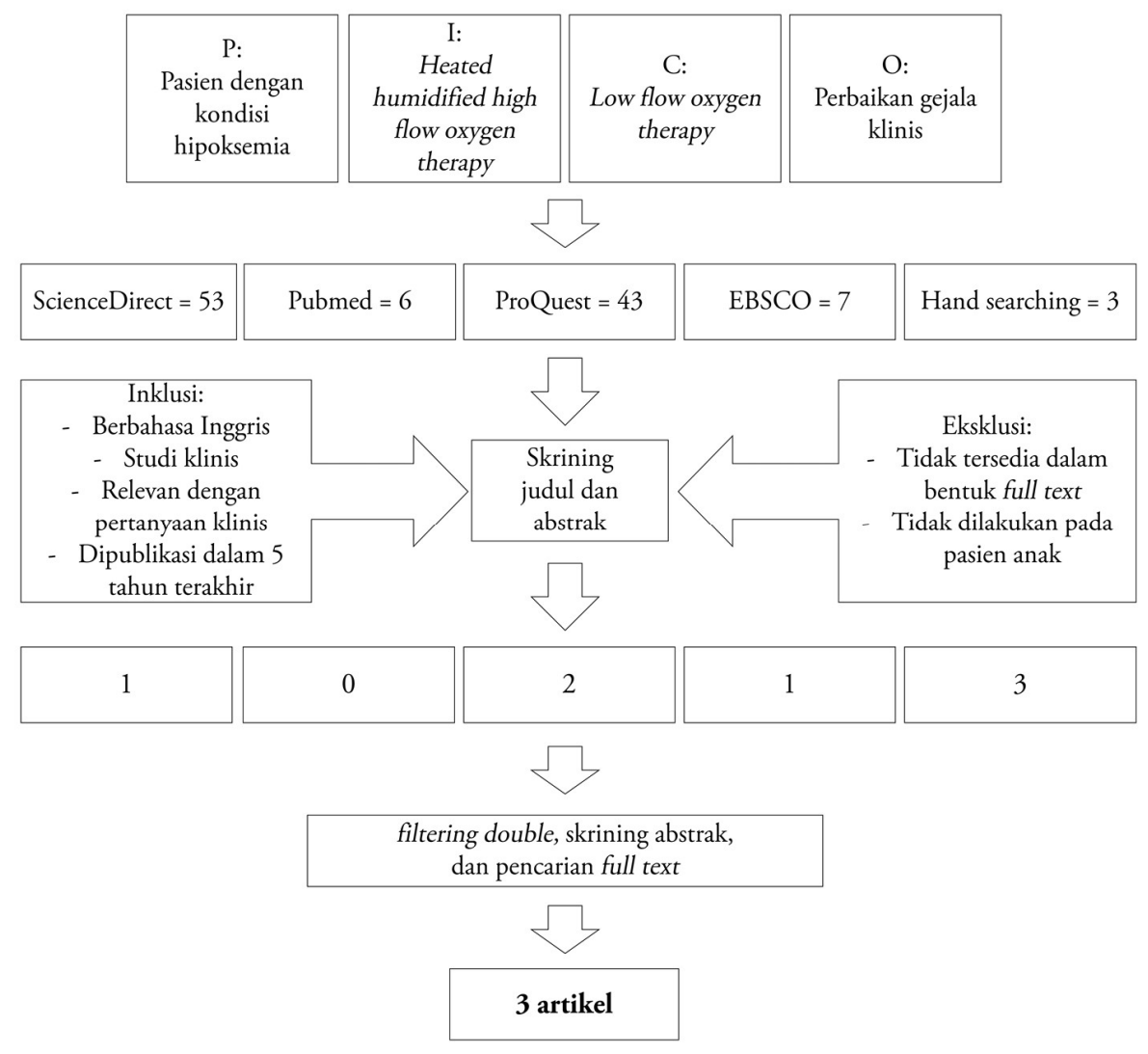

Gambar 2. Desain alur strategi penelusuran pustaka (dilakukan pada tanggal 24 April 2018) 
Yosilia Nursakina dkk: Perbandingan penggunaan heated humidif ied high flow oxygen therapy dan low flow oxygen therapy pada pasien hipoksemia

Tabel 1. Hasil telaah kritis berdasarkan kriteria evidence based medicine, University of Oxford

\begin{tabular}{|c|c|c|c|c|c|c|c|c|c|c|c|c|}
\hline \multirow[b]{2}{*}{ Artikel } & \multirow[b]{2}{*}{ Tahun } & \multicolumn{7}{|c|}{ Validity } & \multicolumn{4}{|c|}{ Relevance } \\
\hline & & 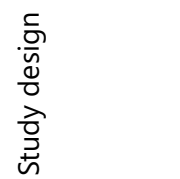 & 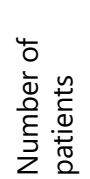 & 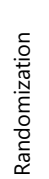 & 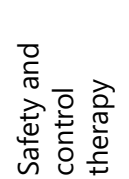 & $\begin{array}{l}\stackrel{g}{\bar{D}} \\
\frac{.}{\bar{D}}\end{array}$ & 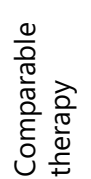 & 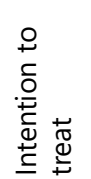 & 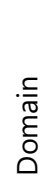 & 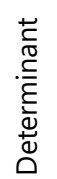 & 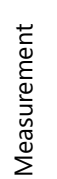 & 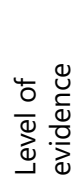 \\
\hline $\begin{array}{l}\text { Mayfield } \\
\text { S dkk }\end{array}$ & 2014 & Pilot study & 94 & - & + & - & + & - & + & + & + & 3 \\
\hline $\begin{array}{l}\text { Kepreotes } \\
\text { E dkk }\end{array}$ & 2017 & $\begin{array}{l}\text { Randomized } \\
\text { controlled } \\
\text { trial }\end{array}$ & 395 & + & + & - & + & + & + & + & + & $2 B$ \\
\hline $\begin{array}{l}\text { Franklin } \\
\text { D dkk }\end{array}$ & 2018 & $\begin{array}{l}\text { Randomized } \\
\text { controlled } \\
\text { trial }\end{array}$ & $\begin{array}{l}147 \\
2\end{array}$ & + & + & - & + & - & + & + & + & $2 B$ \\
\hline
\end{tabular}

\section{Hasil penelusuran}

1. Studi pendahuluan: High-flow nasal cannula oxygen therapy for infants with bronchiolitis: Pilot study (Level of Evidence III)

Mayfield $\mathrm{dkk}^{6}$ melakukan studi pendahuluan mengenai penggunaan high flow nasal cannula (HFNC) pada bangsal pasien anak. Studi ini melibatkan 94 subjek berusia < 12 bulan dengan SpO2 < 94\% pada udara ruangan. Hasilnya, terdapat penurunan detak jantung pada kedua kelompok $(\mathrm{p}<0,001)$. Pada kelompok yang diberikan HFNC, rata-rata detak jantung berkurang drastis dalam 60 menit dari 158 kali/ menit (95\% KI; 154-164) menjadi 144 kali/ menit (95\% KI; 138-150). Kecepatan pernapasan juga menurun secara signifikan pada kedua grup $(p=0,05)$. Rerata kecepatan pernapasan pada kelompok HNFC turun dari $54 \mathrm{kali} / \mathrm{menit}$ (95\% KI; 51-57) menjadi $51 \mathrm{kali} / \mathrm{menit}(95 \%$ KI; 48-69). Pasien dengan HNFC juga memiliki kemungkinan 4 kali lebih kecil untuk pindah rawat pasien ke PICU ( $\mathrm{p}=0,043$; ARR 18\%; NNT 5,55), sehingga memiliki angka kegagalan terapi lebih rendah daripada tata laksana standar. Tidak terdapat perbedaan signifikan pada durasi rawat inap.

2. Uji klinis acak terkontrol: High-flow warm humidified oxygen versus standard low-flow nasal cannula oxygen for moderate bronchiolitis (HFWHO
RCT): an open, phase 4, randomized controlled trial (Level of Evidence II)

Kepreotes $\mathrm{dkk}^{7}$ melakukan uji klinis acak terkontrol untuk membandingkan keamanan dan efektivitas penggunaan high-flow warm humidified oxygen (HFWHO) dengan terapi standar. Studi ini melibatkan 395 subjek di bawah 24 bulan dengan diagnosis klinis bronkiolitis dan membutuhkan terapi oksigen. Penurunan detak jantung pada kelompok HFWHO lebih tinggi daripada kelompok standar, yakni -27,0 (-31,1 hingga -22,9) dan -23,0 (27,1 hingga -19,0; p $=0,59)$ secara berturut-turut. Skor kenyamanan HFWHO (4 [3-4]) juga lebih tinggi daripada terapi standar $(3[3-4 ; p=0,017])$. Selain itu, studi ini melaporkan bahwa angka kegagalan terapi HFWHO (14\%) lebih kecil daripada terapi standar (33\%) ( $\mathrm{p}=0,0016$; ARR 20\%; NNT $5,00)$. Walaupun demikian, penurunan frekuensi napas tidak jauh berbeda antara kedua kelompok, yakni kelompok HFWHO sebanyak -12,9 (-15,7 hingga -10) dan $-13,5$ pada kelompok standar $(-16,0$ hingga $-10,9 ; \mathrm{p}=0,28)$. Angka time to weaning off oxygen juga tidak berbeda signifikan antara kelompok terapi standar (24 jam [95\% KI; 18-28]) dan kelompok HFWHO (20 jam [95\% KI; 17-34]).

3. Uji klinis acak terkontrol: $A$ randomized trial of high-flow oxygen therapy in infants with bronchiolitis (Level of Evidence II) 
Franklin $\mathrm{dkk}^{8}$ membandingkan penggunaan HHHFNC dibandingkan dengan terapi standar. Studi ini melibatkan 1472 subjek berusia kurang dari 12 bulan dengan gejala klinis bronkiolitis dan membutuhkan terapi oksigen. Hasilnya, terdapat perbedaan angka kegagalan terapi sebesar $12 \%$ pada grup high-flow dan 23\% pada grup terapi standar (ARR 11\%; $<<0,001$; NNT 9,09). Tidak terdapat perbedaan signifikan pada lama rawat inap, saturasi oksigen, dan detak jantung. Walaupun demikian, terdapat perbedaan frekuensi pernapasan, kelompok terapi standar memiliki angka lebih rendah $(54,6 \pm 12,4)$ daripada kelompok HHHFNC $(62,6 \pm 15,2)$.

\section{Pembahasan}

Heated humidified high flow nasal cannula (HHHFNC) semakin sering digunakan dan perlahan menggantikan metode nasal continuous positive airway pressure (CPAP) di negara maju. Pasien dengan hipoksemia membutuhkan aliran inspirasi lebih tinggi dari kanula nasal biasa, oleh sebab itu HHHFNC menggunakan kombinasi udara dan oksigen pada kecepatan lebih tinggi daripada aliran inspirasi pasien. Sejumlah studi menggunakan kecepatan $21 / \mathrm{kgBB} /$ menit dimana kecepatan tersebut dapat menurunkan tekanan berlebih pada paru dan mengurangi kerja pernapasan. ${ }^{7}$ Dalam studi Mayfield $\mathrm{dkk}^{6}$ dan Franklin dkk, ${ }^{7}$ digunakan kecepatan aliran oksigen $2 \mathrm{l} / \mathrm{kg} /$ menit, sedangkan Kepreotes $\mathrm{dkk}^{8} 1 \mathrm{l} / \mathrm{kg} /$ menit.

Alat ini terdiri atas kanula yang disesuaikan dengan ukuran lubang hidung, air-oxygen gas blender, dan gas analyser. Kecepatan maksimalnya mencapai $40-601 /$ menit dengan suhu berkisar $33-43^{\circ} \mathrm{C}$ dan kelembaban 95-100\%. Generator gas terdiri atas 3 tipe: 1 ) blender udara/oksigen, tersambung dengan sistem pelembab dan pemanas gas; 2) turbine ditambah dengan humidifier; dan 3) CPAP atau ventilator konvensional dengan sirkuit pernapasan high flow nasal cannula yang tersambung dengan humidifier. Humidifier yang digunakan dapat berupa disposable vapour transfer cartridge, bubble humidifier, atau heated plate humidifier. Alat ini dapat digunakan hingga 30 hari. $^{9}$

Aliran udara yang hangat dan lembab dapat mengurangi dehidrasi permukaan saluran napas, sensasi gangguan napas, dan mulut kering. Terapi ini juga dapat meningkatkan mucocilliary clearance,

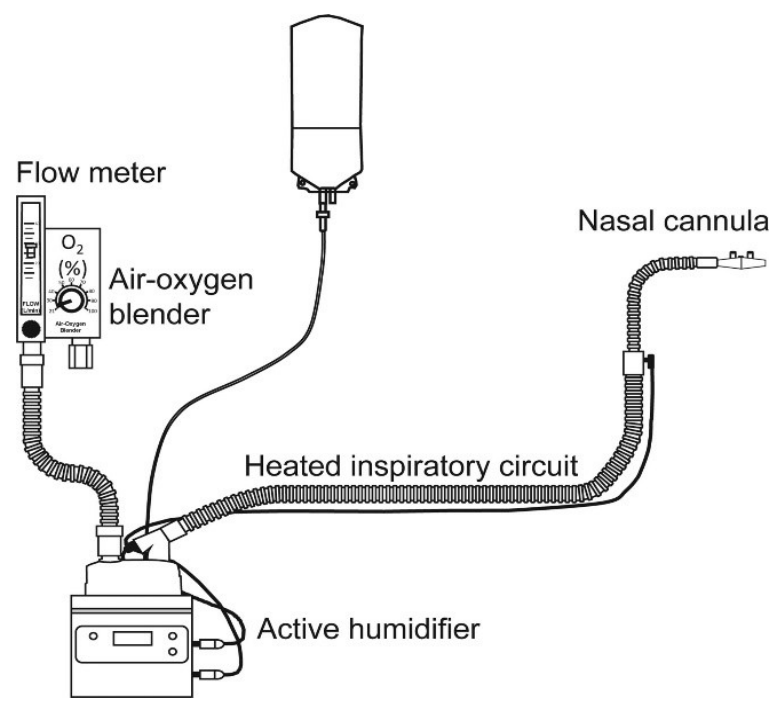

Gambar 3. Skema alat HHHFNC Sumber : Nishimura M10

sehingga dapat menjaga sistem pertahanan saluran napas sekunder dan mengurangi risiko infeksi pada pasien. ${ }^{11}$

Penghantaran oksigen pada metode ini juga lebih baik daripada low flow oxygen therapy, dikarenakan efeknya terhadap ruang rugi orofaringeal dimana HHHFNC dapat mengeluarkan gas rendah oksigen pada akhir ekspirasi. ${ }^{11}$ Studi yang dilakukan Rudolf $\mathrm{dkk}^{12}$ melaporkan bahwa terdapat kadar $\mathrm{CO}_{2}$ pada low flow oxygen therapy $(0,24 \mathrm{kPa} /$ menit) lebih tinggi daripada kelompok dengan high flow oxygen therapy $(0,15 \mathrm{kPa} /$ menit $)$. Studi lain yang dilakukan oleh Chatila $\mathrm{dkk}^{13}$ pun menunjukkan bahwa pasien PPOK yang diberikan HHHFNC $(10,0 \pm 2,4$ menit) dapat berolahraga lebih lama daripada pasien yang diberikan low flow oxygen therapy (8,2 $\pm 4,3$ menit). Pasien dengan HHHFNC juga mengalami dispnea lebih jarang, fungsi pernapasan yang lebih baik, serta tekanan arterial lebih rendah.

Kecepatan aliran yang tinggi dapat menjadikan tekanan faringeal menjadi positif maksimum $(6 \mathrm{~cm}$ $\left.\mathrm{H}_{2} \mathrm{O}\right)$ pada saat ekspirasi. Tekanan ini tidak hanya ditentukan oleh aliran, tetapi juga rasio prong/ hidung dan tertutup atau terbukanya mulut. Sebuah studi yang dilakukan oleh Milesi $\mathrm{dkk}^{14}$ menunjukkan bahwa kecepatan aliran 1,5-2 1/kg/menit dapat menimbulkan tekanan faring positif selama seluruh siklus pernapasan. Dengan tekanan yang positif, HHHFNC juga menghasilkan tekanan paru yang 
membesar, sehingga menginduksi rekrutmen alveolar. Studi yang melibatkan 20 pasien pasca operasi jantung menunjukkan bahwa HHHFNC dapat menurunkan frekuensi pernapasan serta memperbaiki oksigenasi melalui peningkatan end-expiratory lung volume (EELV) dan volume tidal. Hal ini merupakan temuan yang bermanfaat bagi pasien dengan indeks massa tubuh yang tinggi. Resistensi nasofaringeal juga berkurang akibat meningkatnya aliran udara inspirasi. Hal ini ditunjang dengan sebuah studi perbandingan efek kecepatan aliran terhadap resistensi yang menunjukkan resistensi sebesar $783 \mathrm{cmH} 2 \mathrm{O} / \mathrm{l} / \mathrm{s}$ pada HHHFNC dan $280 \mathrm{cmH} 2 \mathrm{O} / \mathrm{l} / \mathrm{s}$ pada CPAP. Walaupun demikian, mekanisme berkurangnya resistensi nasofaring pada saat inspirasi kemungkinan disebabkan oleh peningkatan aliran udara inspirasi. ${ }^{15}$

Selain itu, sejumlah studi juga menunjukkan bahwa HHHFNC juga menurunkan angka mortalitas, menurunkan kemungkinan dilakukannya intubasi, dan kelangsungan hidup yang lebih baik. Walaupun demikian, metode ini juga memiliki sejumlah kelemahan, seperti tingkat kebisingan mencapai $80 \mathrm{~dB}$, pneumotoraks, pneumomediastinum, serta risiko air leak syndrome. Kesulitan lainnya ialah variasi yang besar terhadap tekanan yang dihasilkan pada saluran napas. ${ }^{8}$

Berdasarkan 3 studi yang telah dianalisis dalam EBCR ini, terdapat 1 studi pendahuluan dan 2 RCT yang menunjukkan bahwa HHHFNC aman digunakan pada pasien anak dan memiliki angka keberhasilan terapi yang lebih tinggi daripada low flow oxygen therapy. Tidak ada perbedaan durasi rawat inap, kecepatan pernapasan, dan saturasi oksigen yang signifikan pada ketiga studi tersebut. Angka keberhasilan terapi yang tinggi dapat disebabkan oleh kelebihan-kelebihan HHHFNC yang telah dijelaskan sebelumnya. ${ }^{6-8}$

Studi pendahuluan yang dilakukan oleh Mayfield ${ }^{6}$ membandingkan antara pasien yang diberikan HFNC dengan tata laksana standar atau kanula nasal biasa. Studi ini menunjukkan bahwa HFNC menurunkan kecepatan pernapasan dengan signifikan dalam 60 menit pertama, memiliki kemungkinan 4 kali lebih kecil untuk pindah rawat pasien ke PICU ( $\mathrm{p}=0,043$; ARR 18\%; NNT 5,55), serta angka kegagalan terapi lebih rendah daripada tata laksana standar. Studi ini juga menyatakan bahwa penggunaan HFNC lebih awal merupakan kunci dari pencegahan progresi obstruksi saluran napas dan atelektasis. Tidak terdapat efek samping berupa pneumotoraks, bradikardi, bradipnea, atau intubasi. Kelemahan dari studi ini ialah tidak dirandomisasi serta jumlah sampel yang kurang banyak sehingga kesimpulan yang diambil kurang kuat.

Studi randomized controlled trial yang dilakukan oleh Kepreotes $\mathrm{dkk}^{7}$ membandingkan antara WFWHO dengan terapi standar. Studi ini melaporkan bahwa angka kegagalan terapi HFWHO (14\%) lebih kecil daripada terapi standar (33\%; $\mathrm{p}=0,0016$; ARR 20\%; NNT 5,00). Subjek dalam studi ini mengalami 4 kejadian efek samping berupa desaturase oksigen dan kondensasi inhalasi pada grup HFWHO, serta 1 insiden berupa saluran oksigen yang mengalami diskoneksi pada grup terapi standar. Tidak terdapat efek samping terkait oksigen yang serius, seperti pneumotoraks, cedera akibat tekanan tinggi, perdarahan, ataupun kematian. Kelemahan dari studi ini ialah bersifat single-centre sehingga hasil yang ada belum tentu dapat digeneralisir di tempat lain. Selain itu, penelitian ini juga tidak memiliki penyamaran randomisasi, sehingga terdapat risiko performance bias.

Dalam randomized controlled trial yang dilakukan oleh Franklin dkk, ${ }^{8}$ penggunaan HHHFNC dibandingkan dengan terapi standar. Hasilnya, terdapat perbedaan angka kegagalan terapi sebesar $12 \%$ pada grup HHHFNC dan $23 \%$ pada grup terapi standar (ARR 11\%; $<<0,001 ;$ NNT 9,09). Tidak terdapat perbedaan signifikan pada durasi rawat inap atau durasi terapi oksigen. Masing-masing grup memiliki 1 kasus pneumotoraks $(<1 \%$ bayi). Kelemahan dari studi ini ialah tidak terdapat penyamaran randomisasi.

Pada kasus ini, pasien mendapatkan HHHFNC dengan kecepatan 12 l/menit dan $\mathrm{FiO}_{2} 30 \%$, lalu dinaikkan/diturunkan secara bertahap sesuai dengan keadaan klinis dan hasil analisa gas darah pasien. Hal ini sudah sesuai dengan literatur yang ada. Dalam kasus ini, terjadi perbaikan klinis berupa perbaikan usaha napas, berkurangnya penggunaan otot bantu napas, serta perbaikan tanda vital dan analisis gas darah. Pemantauan yang intensif perlu dilakukan agar toksisitas oksigen atau komplikasi lain akibat terapi oksigen dapat dicegah atau ditangani lebih cepat.

Terdapat sejumlah tantangan dalam mengaplikasikan HHHFNC di Indonesia. Saat ini, belum ada konsensus atau uraian lebih lanjut mengenai terapi oksigen yang baku pada pasien dengan hipoksemia, baik dari segi alat maupun kecepatan aliran oksigen yang digunakan. Kecepatan aliran oksigen yang ideal digunakan pada pasien hipoksemia juga belum pasti. Berdasarkan studi yang ditinjau, dua diantaranya 
menggunakan kecepatan $21 / \mathrm{kgBB} /$ menit sedangkan referensi lain menggunakan kecepatan $1 \mathrm{l} / \mathrm{kgBB} /$ menit. Diperlukan penelitian lebih lanjut mengenai indikasi dan kecepatan aliran oksigen yang ideal digunakan pada HHHFNC. Selain itu, rentang variasi efek dari metode ini juga sangat luas sehingga membutuhkan tenaga ahli yang berpengalaman dalam memberikan terapi oksigen. Fasilitas HHHFNC juga masih terbatas. Biaya alatnya juga lebih tinggi daripada kanula nasal biasa, walaupun secara keseluruhan lebih rendah pembiayaannya dibandingkan terapi standar karena angka keberhasilan terapinya yang tinggi.

\section{Kesimpulan}

Penggunaan heated humidified high flow oxygen therapy terbukti aman dan dapat meningkatkan angka keberhasilan terapi pada pasien dengan hipoksemia. Pasien yang ada dalam ilustrasi kasus dapat diberikan terapi ini dengan pemantauan yang intensif untuk mencegah kegagalan terapi atau munculnya efek samping yang tidak diinginkan. Dengan keterbatasan yang terdapat pada studi ini, disarankan untuk melakukan penelitian mengenai kecepatan aliran oksigen yang ideal serta indikasi absolut dan relatif dari digunakannya metode ini.

\section{Daftar pustaka}

1. Singh V, Gupta P, Khatana S, Bhagol A. Supplemental oxygen therapy: Important considerations in oral and maxillofacial surgery. Natl J Maxillofac Surg 2011;2:10-4.

2. Alwi EH. Terapi oksigen. Dalam: Pudjiadi AH, Latief B, Budiwardhana N. Buku Ajar pediatri gawat darurat. Jakarta: Badan Penerbit IDAI; 2011.h.51-8.
3. Powell FL, Heldt GP, Haddad GG. Respiratory physiology. Dalam: Nichols DG, penyunting. Roger's textbook of pediatric intensive care. Edisi ke-4. Philadelphia: Lippincott Williams \& Wilkins; 2008.h.631-61.

4. El-Khatib MF. High-flow nasal cannula oxygen therapy during hypoxemic respiratory failure. Respir Care 2012;57:1696-8.

5. Corley A, Caruana LR, Barnett AG, Tronstad O, Fraser FJ. Oxygen delivery through high-flow nasal cannulae increase end-expiratory lung volume and reduce respiratory in postcardiac surgical patients. Br J Anaesth 2011;107:998-1004.

6. Mayfield S, Bogossian F, O'Malley L, Schibler A. High-flow nasal cannula oxygen therapy for infants with bronchiolitis: Pilot study. J Paediatr Child Health 2014;50:373-8.

7. Kepreotes E, Whitehead B, Attia J, dkk. High-flow warm humidified oxygen versus standard low-flow nasal cannula oxygen for moderate bronchiolitis (HFWHO RCT): an open, phase 4, randomized controlled trial. Lancet 2017;369:930-9.

8. Franklin D, Babl FE, Schlapbach LJ, dkk. A randomized trial of high-flow oxygen therapy in infants with bronchiolitis. $\mathrm{N}$ Engl J Med 2018;178:1121-31.

9. Kashani NA, Kumar R. High-flow nasal oxygen therapy. BJA Education 2017:17:63-7.

10. Nishimura M. High-flow nasal cannula oxygen therapy in adults: physiological benefits, indication, clinical benefits, and adverse effects. Respir Care 2016;61:529-41.

11. Zhang J, Lin L, Pan K, Zhou J, Huang X. High-flow nasal cannula therapy for adult patients J Int Med Res 2016;44:1200-1211.

12. Hernandez G, Roca O, Colinas L. High-flow nasal cannula support therapy: new insights and improving performance. Crit Care 2017;21:62-73.

13. Chatila W, Nugent T, Vance G, dkk. The effects of high-flow vs low-flow oxygen on exercise in advanced obstructive airways disease. Chest 2004;126:1108-15

14. Milesi C, Baleine J, Matecki S, dkk. Is treatment with a high flow nasal cannula effective in acute viral bronchiolitis? A physiologic study. Intensive Care Med 2013;39:1088-94. 